\title{
33. MAGNETIC LOGGING AND IN-SITU MAGNETOSTRATIGRAPHY: A FIELD TEST ${ }^{1}$
}

\author{
P. Roperch, ${ }^{2}$ V. Barthès,${ }^{3}$ J. Pocachard, ${ }^{3}$ J.-Y. Collot, ${ }^{2}$ and T. Chabernaud ${ }^{4}$
}

\begin{abstract}
During Ocean Drilling Program Leg 134 (Vanuatu), geological high sensitivity magnetic tools (GHMT) developed by CEA-LETI and TOTAL were used at two drill sites. GHMT combine two sensors, a proton magnetometer for total magnetic field measurements with an operational accuracy of 0.1 nanoteslas (nT), and a highly sensitive induction tool to measure the magnetic susceptibility with an operational accuracy of a few $10^{-6} \mathrm{SI}$ units.

Hole 829A was drilled through an accretionary prism and the downhole measurements of susceptibility correlate well with other well-log physical properties. Sharp susceptibility contrasts between chalk and volcanic silt sediment provide complementary data that help define the lithostratigraphic units.

At Hole 831B magnetic susceptibility and total field measurements were performed through a 700-m reef carbonate sequence of a guyot deposited on top of an andesitic volcano. The downhole magnetic susceptibility is very low and the amplitude of peak-to-peak anomalies is less than a few $10^{-5} \mathrm{SI}$ units. Based on the repeatability of the measurements, the accuracy of the magnetic logging measurements was demonstrated to be excellent. Total magnetic field data at Hole 831B reveal low magnetic anomalies of 0.5 to $5 \mathrm{nT}$ and the measurement of a complete repeat section indicates an accuracy of 0.1 to $0.2 \mathrm{nT}$. Due to the inclination of the earth's magnetic field in this area $\left(\sim-40^{\circ}\right)$ and the very low magnetic susceptibility of the carbonate, the contribution of the induced magnetization to the total field measured in the hole is negligible. Unfortunately, because the core recovery was extremely poor $(<5 \%)$ no detailed comparison between the core measurements and the downhole magnetic data could be made. Most samples have a diamagnetic susceptibility and very low intensity of remanent magnetization $\left(<10^{-4} \mathrm{~A} / \mathrm{m}\right)$, but a few samples have a stable remanent magnetization up to $0.005 \mathrm{~A} / \mathrm{m}$. These variations of the intensity of the remanent magnetization suggest a very heterogeneous distribution of the magnetization in the carbonate sequence that could explain the magnetic field anomalies measured in these weakly magnetized rocks.
\end{abstract}

\section{INTRODUCTION}

Magnetostratigraphic investigations of sedimentary and volcanic sequences and studies of seafloor marine magnetic anomalies have enabled the construction of a geomagnetic polarity reversal time scale that covers the last 165 m.y. (Cox, 1983; Berggren et al., 1985). Magnetic measurements of core sediment recovered by the Deep Sea Drilling Project (DSDP) and the Ocean Drilling Program (ODP) have permitted magnetostratigraphy to become a powerful tool for between-core correlations and absolute dating. Comparison of the observed pattern of magnetic reversals recorded by a sedimentary section with the reference geomagnetic time scale provides strong constraints of biostratigraphic markers. However, the determination of magnetostratigraphy from core samples is a time-consuming laboratory procedure and depends upon core recovery.

Measurements of numerous physical and chemical properties of rocks in the boreholes have played a major role in the mining and oil industry. In contrast, the scientific community involved in the DSDP and ODP scientific research programs has until recently emphasized the study of cores. Before Leg 134 magnetic logging experiments were conducted during DSDP and ODP legs only for volcanic units characterized by strong magnetic anomalies. The first experiments were conducted on DSDP Legs 68 and 69 by Ponomarev and Nechoroshkov (1983) and later on DSDP Leg 78 (Ponomarev and Nechoroshkov, 1984). A gyroscope-oriented three-axis borehole magnetometer and a susceptibility tool were used in mid-Cretaceous basalts at Hole 418A (ODP Leg 102; Bosum and Scott, 1988). More recently, the in-situ magnetic properties of a gabbro were investigated during ODP Leg

${ }^{1}$ Greene, H.G., Collot, J.-Y., Stokking, L.B., et al., 1994. Proc, ODP, Sci. Results, 134: College Station, TX (Ocean Drilling Program).

${ }_{3}^{2}$ ORSTOM, BP 48, 06230 Villefranche-sur-Mer. France.

${ }^{3}$ CEA-LETI, Centre d'Etudes Nucléaires de Grenoble, 85X - 38041 Grenoble, France.

${ }^{4}$ Borehole Research Group, Lamont-Doherty Earth Observatory, Columbia University, Palisades, NY 10964, U.S.A.
118 (Pariso et al., 1991) with a University of Washington and U.S. Geological Survey three-component magnetometer and susceptibility meter. These magnetic tools were developed to study volcanic basement rocks and are not suitable for use in weakly magnetized sediment. Advances in technology and the interest of the oil industry in logging that could constrain age and sedimentation rate have stimulated the development of borehole magnetic sensors that could determine an in-situ magnetostratigraphy in sediment. This paper focuses on magnetic logging tools recently developed by CEA-LETI and TOTAL (Pocachard et al., 1991) that were used during Leg 134.

To determine the magnetostratigraphy the primary information that needs to be measured is the remanent magnetization of the rocks. In a laboratory experiment it is easy to screen the earth's present magnetic field and to measure the remanent magnetic field directly using a magnetometer. In contrast, magnetic field measurements in a borehole include contributions from the earth's present magnetic field, as well as the remanent magnetization field, and the induced magnetization field. The main magnetic field that originates in the earth's core varies slowly (secular variation), and it can be considered a constant for the duration of the logging experiment (a few hours). In contrast, the field of external origin has diurnal variations with periods and amplitude that cannot be neglected during logging. Variations up to several tens of nanoteslas (nT) can be observed during stormy magnetic periods. The magnetic anomalies expected in a borehole depend on the variations of the natural remanent magnetization vector of the rocks as well as the susceptibility contrasts between sediment layers. Magnetic anomalies of a few hundred of nanoteslas are expected in volcanic rocks with magnetization on the order of $1 \mathrm{~A} / \mathrm{m}$, whereas sediments with magnetization of about $10^{-3}$ $\mathrm{A} / \mathrm{m}$ would produce magnetic anomalies from a few $10^{-1} \mathrm{nT}$ to $1 \mathrm{nT}$. Deep-sea sediments have remanent magnetizations of $10^{-3}$ to $10^{-2}$ $\mathrm{A} / \mathrm{m}$ whereas limestones carry lower magnetizations. Thus, magnetometers with a sensitivity of $10^{-1} \mathrm{nT}$ are required for conducting downhole magnetic logging in sediment.

An accurate retrieval of the direction of the remanent magnetization vector from borehole measurements requires the record of the 
three components of the field (Parker and Daniell, 1979; Gallet and Courtillot, 1988). Pozzi et al. (1988) have shown numerical models of the expected magnetic field components in a hole drilled through horizontal layers, and Gallet and Courtillot (1988) extended the calculations to homogeneous dipping layers. The numerical model of a magnetic anomaly across a polarity transition indicates that a polarity chron thicker than 3 times the borehole diameter will be fully resolved at the $95 \%$ confidence level. A multisensor probe that would provide the three components of the magnetic field as well as the horizontal gradients across the borehole would be a very powerful tool. However, directional fluxgate sensors have an accuracy no better than $1 \mathrm{nT}$ and are sensitive to temperature changes. Another problem is the accuracy in the orientation of the magnetometers. For example, in a total field of $50,000 \mathrm{nT}$ an accuracy of less than $1 \mathrm{nT}$ on each component would require an orientation with an accuracy of $0.001^{\circ}$. These limits in directional magnetometers and in orientation of the tools have led the CEA-LETI and TOTAL groups to develop a total magnetic field magnetometer with high resolution. The high-resolution records provide valuable information from which qualitative interpretations can be attempted, assuming that the magnetization vector is homogeneous within a single layer of infinite extent (Tabbagh et al., 1990; Pozzi et al., unpubl. data).

Assuming a simple model of infinite homogeneous layers, a simple relationship exists between the direction of the magnetization $\left(M_{x}, M_{y}, M_{z}\right)$ and the resulting magnetic induction $\left(\mathrm{B}_{x}, \mathrm{~B}_{y}, \mathrm{~B}_{z}\right)$ at the center of a borehole, thus

$$
\mathrm{B}_{x}=\mu / 2 M_{x} ; \mathrm{B}_{y}=\mu / 2 M_{y} ; \mathrm{B}_{z}=-\mu M z,
$$

where the magnetization $M$ is in $\mathrm{A} / \mathrm{m}$, the magnetic induction in tesla, and $\mu$ is equal to the permeability of free space $\mu_{0}=4 \pi 10^{-7} \mathrm{H} / \mathrm{m}$.

In a borehole drilled in sediment the magnetic field anomaly is very small compared to the earth's field and is difficult to detect in a total field measurement when the magnetic field vector anomaly is normal to the earth's field. For the induced magnetization (and the natural remanent magnetization when collinear with the earth's field) there is no effect measurable on the total field intensity when the inclination (I) of the earth's field is $+35^{\circ}$ or $-35^{\circ}$, following Equation 1 .

$$
\mathrm{B}_{\text {anomaly }}=\mathrm{B}_{0 \chi}\left(1-3 \sin ^{2}[\mathrm{I}]\right) / 2
$$

The magnetic contribution from a given susceptibility varies with the latitude because of the increase in the intensity of the earth's field with latitude and the geometry of the magnetic anomaly vector in a borehole (Eq. 1; Fig. 1). Near the magnetic equator there is a positive contribution that is less than $50 \%$ of the negative induced anomaly observed at about $45^{\circ}$. Sites drilled during Leg 134 are situated at a low latitude (Fig. 1) and the magnetic anomaly produced by the induced magnetization will be reduced.

In this paper we report on magnetic logging experiments conducted at Holes 829A and 831B (Fig. 2). Hole 829A was drilled in an accretionary wedge consisting of imbricated thrust sheets of Pleistocene volcanic silts and brecciated chalks. The total field magnetometer was not used because of time limitations and the difficulties of determining magnetostratigraphy of deformed sediment. The susceptibility tool was used to complement sedimentological characterization of the lithostratigraphic units. At Hole $831 \mathrm{~B}$, drilled through the carbonate cap of an andesitic basemented guyot, both susceptibility and total field magnetometer data were recorded. An attempt to use the total field magnetometer in volcanic-rich silts of Hole 833B in the North Aoba Basin (Fig. 2) failed because the large magnetic gradients were greater than the measuring range of the tool.

\section{INSTRUMENTS}

Total magnetic field and susceptibility measurements were performed using two independent tools developed by CEA-LETI engi- neers (Pocachard et al., 1991). The generic name of the total field magnetometer is nuclear resonance magnetic tool (NRMT); the susceptibility magnetic tool is SUMT. These instruments are packaged according to Schlumberger standards, and data are recorded every 6 in. in accordance with Schlumberger procedures.

The SUMT is a low-frequency induction tool. The volume measured is a cylinder approximately $0.5 \mathrm{~m}$ in radius and $1.5 \mathrm{~m}$ in length. The susceptibility tool provides information about the electrical conductivity. We used this information to match the depth from the other Schlumberger resistivity tools. Before the data processing, the output of the SUMT has an offset of about $-2500 \mathrm{ppm}$. The data processing consists mostly in removing a drift linked to temperature changes. The zero value that corresponds to the transition from paramagnetism to diamagnetism is estimated at a given temperature. The transfer rate from ppm to SI units is about $1 \mathrm{ppm}$ to $10^{-6}$ SI. Augustin (1990) compared core measurements with SUMT results from drill holes in the Bassin de Paris and showed that SUMT variations are linearly related to susceptibility contrasts. The NRMT consists of a Overhauser proton magnetometer with a peak-to-peak measurement noise better than $0.1 \mathrm{nT}$.

\section{MAGNETIC SUSCEPTIBILITY LOGGING (SITE 829)}

The major lithostratigraphic units recovered during drilling at Site 829 correspond to a Pleistocene clayey volcanic silt sequence from 0 to 60.5 meters below seafloor (mbsf) above a foraminiferal chalk of late Oligocene age from 60.5 to $99.4 \mathrm{mbsf}$. From 99.4 to $171.9 \mathrm{mbsf}$ there is a volcanic silt sequence of Pleistocene age, and the contact with the overlying Oligocene sediment corresponds to one of the major thrusts. Below this thick layer of silt the most characteristic lithology is brecciated chalk. Below 400 mbsf volcanic breccias are also found in a complex tectonic melange.

The magnetic susceptibility was recorded at a speed of $3600 \mathrm{ft} / \mathrm{hr}$ from 425 to 52 mbsf. Core recovery at Hole 829 A was only about $20 \%$, and only a rough comparison could be made between whole core measurements and logging data (Collot, Greene, Stokking, et al., 1992).

Susceptibility data compare well with other standard logging data. Correlations of susceptibility data with the calcium content measured using the geochemical tool and with gamma rays are obvious (Fig. 3). Large changes in facies are observed in all logs. Susceptibility contrasts between volcanic silts and deep-sea sediment are large and the transitions observed in the susceptibility log are slightly better defined than in the other logs. The sharp boundary observed at $100 \mathrm{mbsf}$ corresponds to the upper thrust. The abruptness of this contact suggests that little melange has occurred between the two type of facies during thrusting even within these unconsolidated sediments. In contrast, a more complex double thrust is observed from 170 to 190 mbsf. From 190 to 400 mbsf the chalk breccia does not involve a significant quantity of volcanic silts, although evidence for volcanic materials are found in the imbricated thrust sheets between 400 and 420 mbsf. From 253 to 257 mbsf there is a large peak in the spectral gamma ray that is not correlated with susceptibility data, which suggests that volcanic sediments are not the cause of this peak.

The chalk breccias drilled at Site 829 are interpreted as accreted chalks from the North d'Entrecasteaux Ridge. Drilling at Site 828 on the d'Entrecasteaux Ridge indicates that the sedimentary sequence is composed of a 60-m-thick clayey volcanic silt on top of a thin cover of foraminiferal ooze that overlie a 25 -m-thick unit of Oligocene chalks. In addition to the strong contrast in susceptibility between the chalk and the volcanic silt, the magnetic susceptibility, measured in whole cores on the shipboard multisensor track from Site 828, also permit foraminiferal oozes $\left(\chi=10^{-5}\right.$ to $\left.10^{-4} \mathrm{SI}\right)$ to be distinguished from the nannofossil chalk $\left(\chi=10^{-3}\right.$ to $\left.2 \times 10^{-3} \mathrm{SI}\right)$. Figure 4 compares the whole-core susceptibility record at Site 828 and logging data at Site 829 . The contrasts observed in the susceptibility log agree with those observed on the ridge, suggesting that both foraminiferal oozes 


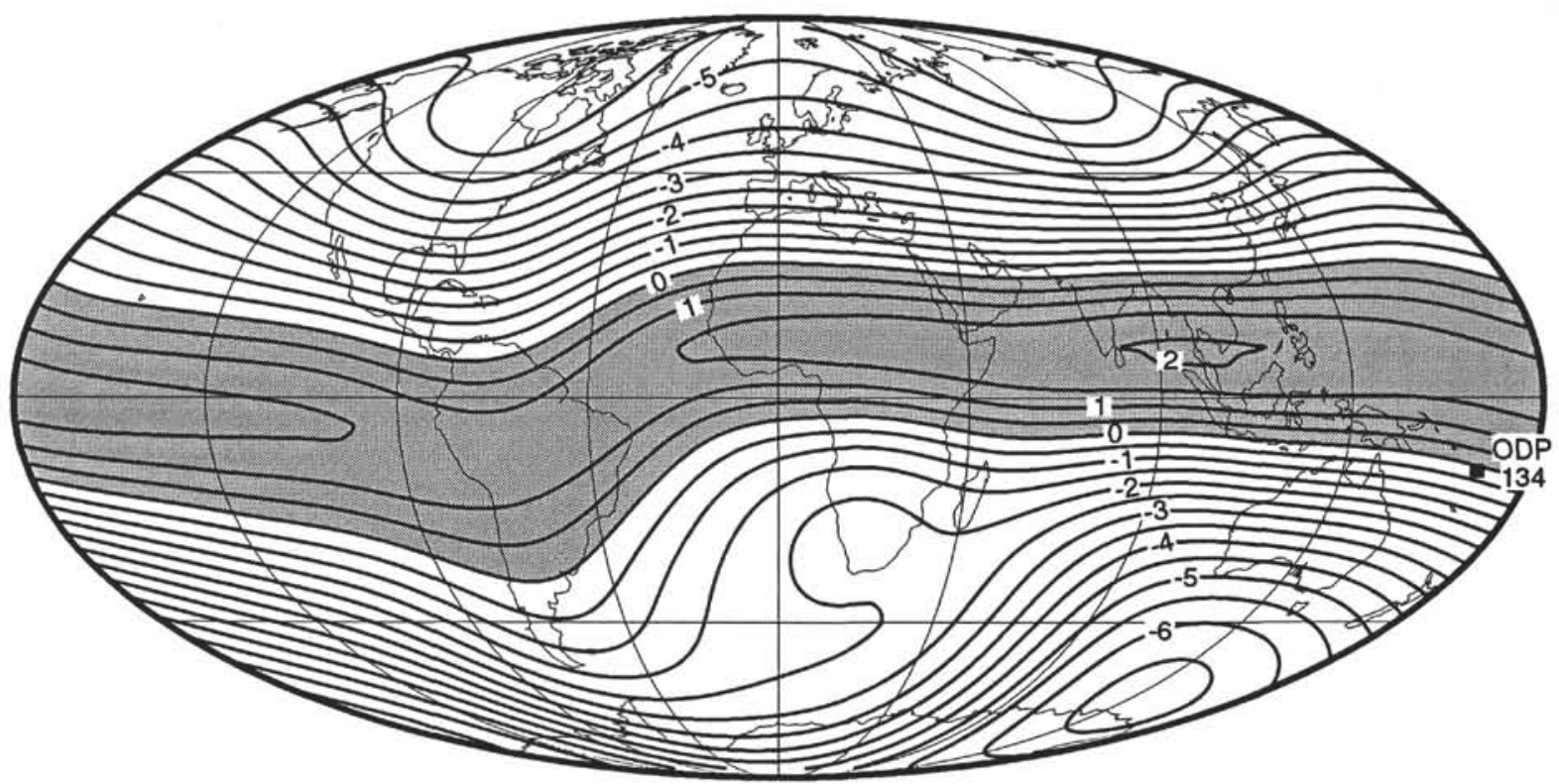

Figure 1. Map of the iso-anomaly expected in a borehole due to the induced magnetization and recorded by a total magnetic field experiment. Iso-anomaly lines are in $\mathrm{nT}$. The shaded area shows the locations where a positive anomaly is found. The magnetic anomaly varies from -7 $\mathrm{nT}$ to about $2 \mathrm{nT}$ for a susceptibility contrast of $10^{-4} \mathrm{SI}$. The increase of the earth's field intensity with latitude accounts only for less than one half of the intensity anomaly variations with latitude.

and nannofossil chalk or ooze were accreted. From 200 to $400 \mathrm{mbsf}$ we can also identify on the susceptibility log several sedimentary units with thickness of about 20 to $30 \mathrm{~m}$ that match the record from the ridge (for example, from 330 to $360 \mathrm{mbsf}$ ). We speculate that the section from 200 to $400 \mathrm{mbsf}$ is indeed composed of several sections from the Oligocene to Miocene sediment from the ridge with a relative small amount of Pleistocene silt.

\section{MAGNETIC SUSCEPTIBILITY AND TOTAL MAGNETIC FIELD LOGGING IN A REEF CARBONATE SEQUENCE (SITE 831)}

The Bougainville Guyot, a seamount that rises $3 \mathrm{~km}$ above the abyssal seafloor, clogs the New Hebrides Trench and collides with the New Hebrides Island Arc southwest of Espiritu Santo Island. Site 831 was drilled approximately in the center of an elongated planar surface, $16 \mathrm{~km}$ long by $10 \mathrm{~km}$ wide, at a water depth of about $1080 \mathrm{~m}$ below sea level (mbsl). Drilling at Site 831 indicates that the guyot is composed of a nearly 730-m carbonate and pelagic sedimented cap on top of andesitic brecciated volcanic rocks. Four lithostratigraphic units were described from Hole 831A and Hole 831B. The upper unit consists of pelagic, bioclastic foraminiferal ooze of late Pleistocene to Holocene age. This 17-m thick unit was not logged. Below Unit I down to about $350 \mathrm{mbsf}$ in Hole $831 \mathrm{~B}$, Unit II consists of neritic, coral rudstone and mollusk floatstone with some marine-water carbonate cement. Uranium-thorium (U-Th) radiometric dating (Taylor et al., 1991; Edwards et al., 1991) and strontium (Sr) isotopic dating (Quinn et al., 1991) indicate that the upper $330 \mathrm{~m}$ of largely unaltered aragonite sediments are of Pleistocene age and are younger than 1 Ma. At 360 mbsf, $\mathrm{Sr}$ isotopic dating gives an age of $1.4 \mathrm{Ma}$. Below $400 \mathrm{mbsf}$ to $735 \mathrm{mbsf}$, Unit III is composed of Miocene to Oligocene neritic coral floatstone and foraminiferal grainstone with abundant meteoric carbonate cementation. Strontium isotopic dating gives an age of $10.7 \mathrm{Ma}$ at $\sim 420 \mathrm{mbsf}$. This jump in age from Pleistocene to middle Miocene, observed from 360 to $400 \mathrm{mbsf}$, indicates that the guyot was subaerially exposed and possibly eroded before it subsided to its present depth. The upper $330 \mathrm{~m}$ of Pleistocene carbonate were rapidly accumulated while the guyot started its descent toward the trench.

\section{Magnetic Measurements of Discrete Samples}

The average core recovery rate within the carbonate sequence was extremely poor-about $1 \%$ to $2 \%$. Most cores yielded a few unoriented rounded cobbles. We took 15 samples for susceptibility and natural remanent magnetization (NRM) measurements (Table 1). We must emphasize that the samples recovered during drilling may not be completely representative of the in-situ lithology. The poor recovery may indicate that the samples recovered correspond to the hardest units; soft materials may have been washed away during drilling. Furthermore, each sample was assigned a depth with a minimum uncertainty corresponding to the length of the core barrel $(9.5 \mathrm{~m})$.

Measurements of natural remanent magnetizations were performed using a CTF brand cryogenic magnetometer, and the susceptibility was obtained using a Bartington susceptibility meter. All samples except Sample 134-831B-34R-CC, 5-7 cm, have a diamagnetic susceptibility derived from calcium carbonate.

The range in NRM intensity is greater than the susceptibility range. Negligible NRM intensities correspond to low susceptibilities for most samples. However, the NRM of three samples is greater than $10^{-3} \mathrm{~A} / \mathrm{m}$. Alternating field ( $\mathrm{AF}$ ) demagnetization indicates that the magnetization is a stable characteristic magnetization. These large changes in NRM intensity could indicate measurable magnetic field anomalies in the borehole, whereas the induced magnetization does not contribute to the magnetic field signal.

\section{Magnetic Logging}

The total field and susceptibility measurements were recorded according to Schlumberger procedures. Logging was done at a speed of $1800 \mathrm{ft} / \mathrm{hr}$ for the magnetic field and $3600 \mathrm{ft} / \mathrm{hr}$ for the susceptibility from the bottom of the hole to the entrance of the drill pipe and data were recorded every 6 in. A complete section was repeated to assess the reliability of the in-situ total field measurements. The repeat section for the SUMT corresponds to data recorded downhole while the SUMT tool was lowered to the bottom of the hole. Time constraints and ship operations prevented the use of a linked magnetic reference station near the ship or on the bottom of the seafloor. Instead, a mag- 


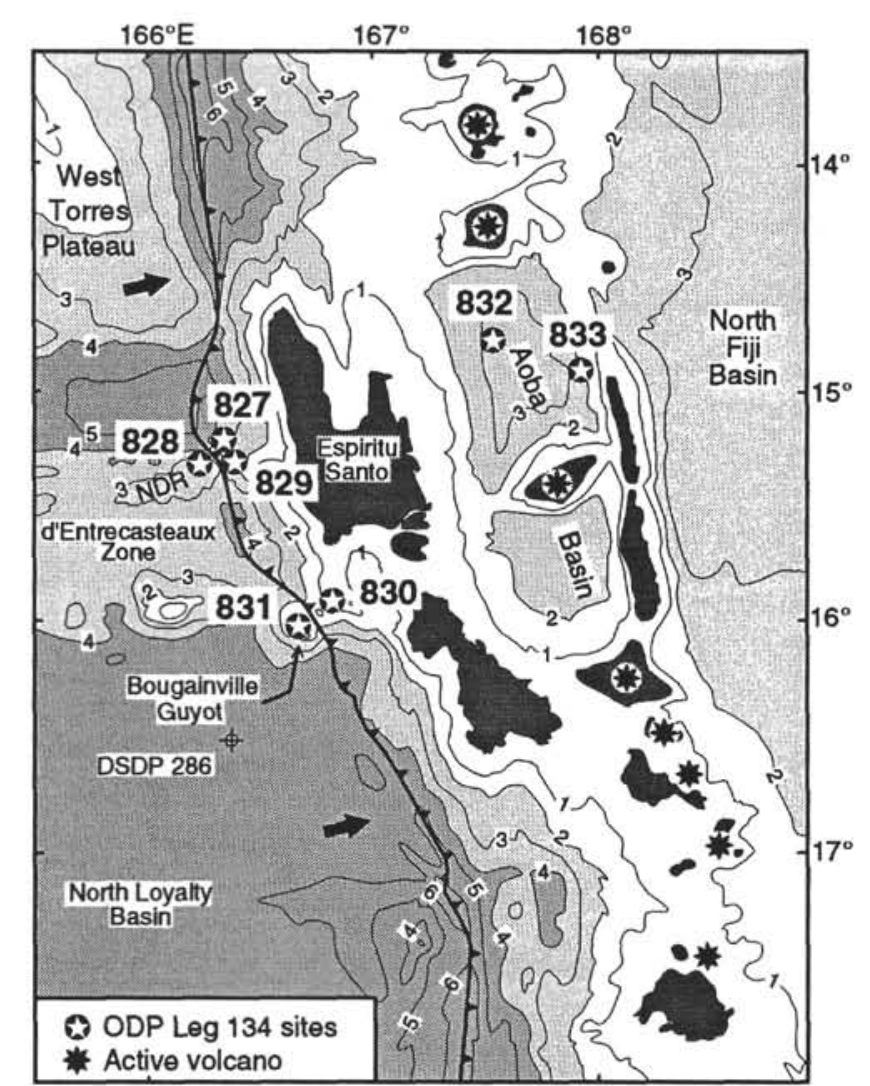

Figure 2. Location map of Leg 134 sites. Bathymetry in meters, bold line with teeth indicates plate boundary, NDR $=$ North d'Entrecasteaux Ridge.

netometer was installed on nearby Espiritu Santo Island, less than 50 $\mathrm{km}$ from the drill sites. Diurnal variations recorded on the island confirm that the downhole experiments were made on a magnetically quiet day. The conductive seawater column also screens highfrequency magnetic variations. Logging at a speed of $1800 \mathrm{ft} / \mathrm{h}$ indicates that $9 \mathrm{~m}$ of section correspond to one min. Thus, magnetic diurnal variations of a few min would corresponds to a wavelength of a few tens of meters. The weather conditions were very good and the ship's heave was minimum. Correlations of two total magnetic logs indicate that the depth shift was no larger than $\pm 0.2 \mathrm{~m}$.

\section{The Magnetic Susceptibility Log}

Magnetic susceptibility in rocks varies from negative susceptibility in pure carbonate limestone $\left(-10^{-5} \mathrm{SI}\right)$, to slightly paramagnetic $\left(10^{-5} \mathrm{SI}\right)$ in limestone, to up to $10^{-2}$ to $10^{-1} \mathrm{SI}$ in volcanics and gabbros. Intermediate susceptibilities $\left(10^{-4}\right.$ to $\left.10^{-3} \mathrm{SI}\right)$ are often found in deep-sea sediments. This large range in susceptibility data is also illustrated in the susceptibility logs obtained at Sites 829 and 831 . This comparison indicates that the susceptibility in the carbonate cap of the guyot is near zero.

At this level of very low magnetic susceptibility, temperature drift is important (Fig. 5). We can reduce the thermal drift effects using an experimental relation between temperature and susceptibility signals (Fig. 6A). Tiny variations with peak-to-peak amplitudes of about 50 ppm are seen on the drift-corrected log (Fig. 6A). Previous experiments in the Bassin de Paris demonstrate that variations in the output of the SUMT sensor reflect susceptibility variations with a transfer rate of 1 ppm unit equal to $10^{-6} \mathrm{SI}$ (Augustin, 1990). The zero level corresponding to the transition from paramagnetism to diamagnetism is located near the minima observed at depths of 575 mbsf and 615 mbsf. The estimate of the zero baseline is accurate within 1 to $2 \times 10^{-5} \mathrm{SI}$.
The comparison of the data recorded while the instrument was moving downhole with data recorded in the log uphole clearly demonstrates a very good repeatability of SUMT measurements with a noise level of less than a few ppm (Fig. 6A). An example of this repeatability is shown in the depth interval 500-600 mbsf enlarged in Figure $6 \mathrm{~B}$. A few peaks are defined with very few points and have a dipolar signature and are interpreted as the results of metallic contamination on the borehole wall. Examples of these contaminants are seen at 517 and $580 \mathrm{mbsf}$. The good repeatability of the downhole and uphole logs at various scales demonstrates that the source of the high-frequency signal is not background noise from the sensor.

To better identify the signal with wavelengths greater than $3 \mathrm{~m}$, a low pass filter was applied to the data (Fig. 6C). With a transfer coefficient of $10^{-6} \mathrm{SI}$ for $1 \mathrm{ppm}$ units, susceptibility contrasts of about 5 to $6 \times 10^{-5}$ SI are identified on the filtered SUMT log (Fig. 6C). Susceptibility contrasts observed in logs are 5 times greater than the susceptibility contrasts measured on discrete samples. Measurements of the discrete samples indicate that the diamagnetism of the carbonate dominates the whole-rock susceptibility of the samples, in contrast to the susceptibility log. The susceptibility logging tool averages over a much larger volume of material. The difference between discrete sample measurements and the in-situ log suggests that the recovered samples do not reflect the whole-rock lithology entirely. The same discrepancy is observed on sonic velocities measured on discrete samples (above $4 \mathrm{~km} / \mathrm{s}$ ) and sonic logs $(<3 \mathrm{~km} / \mathrm{s})$. This is evidence that the recovered samples are from the well-cemented coral units.

The hole diameter at Hole $831 \mathrm{~B}$ is large ( $>15 \mathrm{in}$.) as indicated by the formation microscanner calipers (Fig. 7), but there is no obvious correlation between the susceptibility curve and the hole diameter. Because the SUMT sensor was not centered in the hole, corrections for the variations in the hole diameter are not straightforward. The very good repeatability between the downhole log and the uphole log suggests either that the swinging of the tool was negligible or that the tool followed the same path in the hole and was sliding along the borehole wall although the drift angle of the borehole was less than $5^{\circ}$. We would expect an anticorrelation between the hole diameter and the susceptibility in sediments with moderate to high susceptibility, but changes in borehole diameter principally reflect changes in lithology. At Site 831 , the two minimums in the susceptibility data (575 and $610 \mathrm{mbsf}$ ) appear to correspond to a narrower hole diameter, which may also be linked to a more cemented limestone as indicated by corresponding peaks in the calcium. In contrast, the large peak in the calcium log below $675 \mathrm{mbsf}$ is associated to a terra rosa unit and the SUMT signal is complex.

\section{Total Magnetic Field Log}

Raw data for the first run at Hole 831B are shown on Figure 8. The NRMT record shows two large magnetic anomalies. The upper one corresponds to a pipe effect that can be modeled by a dipole pointing upward along the axis of the pipe. The large wavelength at the bottom of the hole corresponds to the magnetic anomaly produced by the volcanic basement of the guyot. This near effect of the basement was modeled and removed with a dipole in the direction of the earth's magnetic field situated at low depth and $100 \mathrm{~m}$ north of the drilled site. The slope of the middle part of the record indicates a general negative gradient of about $50 \mathrm{nT} / \mathrm{km}$, in contrast to the expected geomagnetic positive gradient. However, this negative gradient agrees with the negative anomaly over the area from surface data (Collot et al., 1985). The model of the anomaly is non-unique and a linear trend was simply removed.

Figure 9 shows very good repeatability between two NRMT logs run more than $1 \mathrm{hr}$ apart. An expanded section from 350 to $500 \mathrm{mbsf}$ shows that tiny magnetic anomalies with amplitude less than $1 \mathrm{nT}$ amplitude are reproducible. The repeatability of both logs indicates minor diurnal variation contribution. The difference between the two runs shows the contribution of external sources. To reduce the effects 

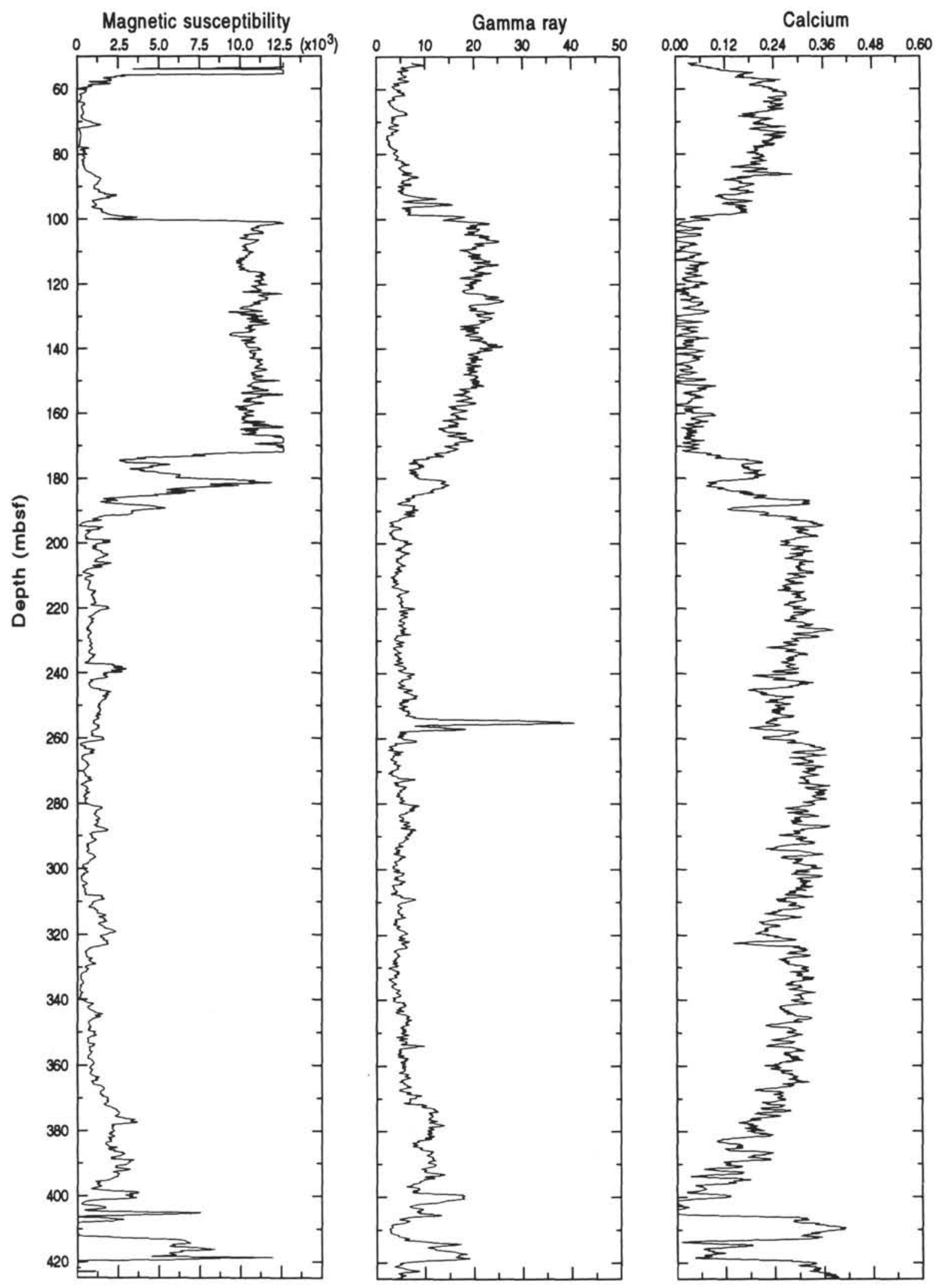

Figure 3. Comparison of the SUMT susceptibility (SI) log with the calcium log from the geochemical tool and the spectral gamma ray (API) log at Hole 829A. 


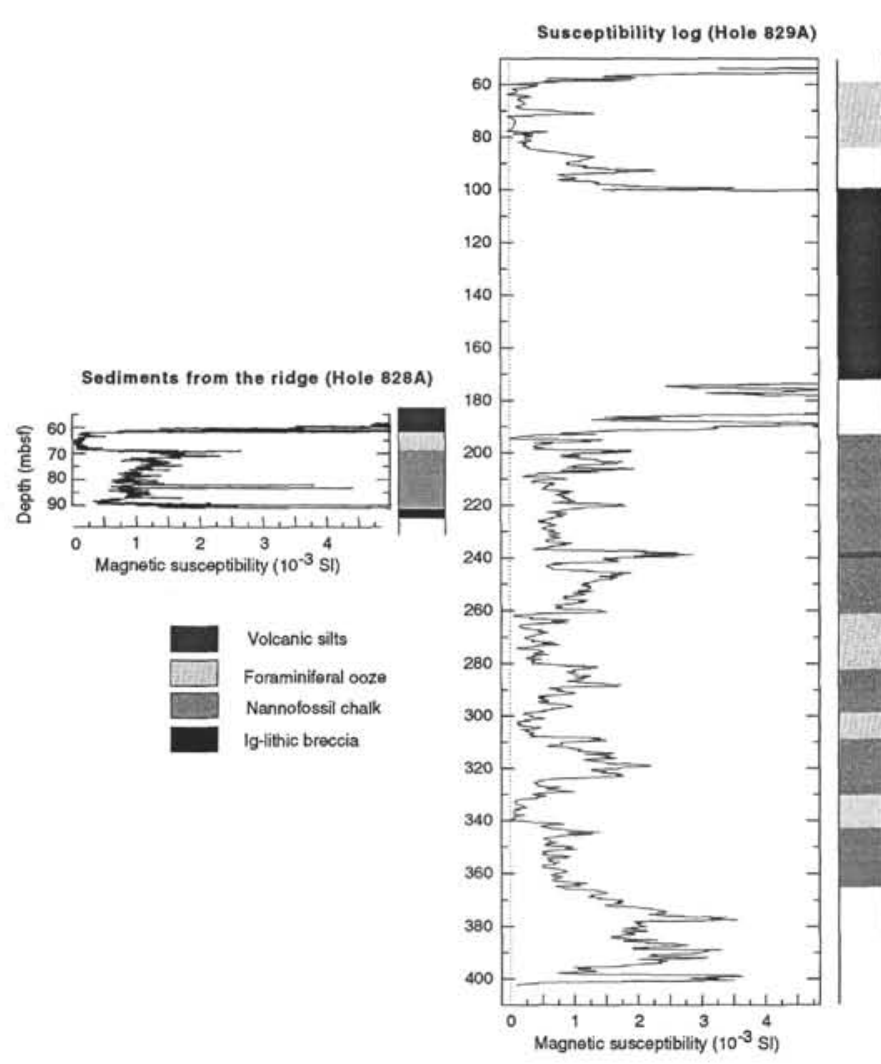

Figure 4. Comparison of the susceptibility data measured in whole cores from Hole $828 \mathrm{~A}$ with the logging data from Hole $829 \mathrm{~A}$. The same susceptibility and depth scales are used for both holes. The susceptibility log from Hole 829A suggests that foraminiferal ooze and nannofossil chalk from the ridge were accreted to the arc.

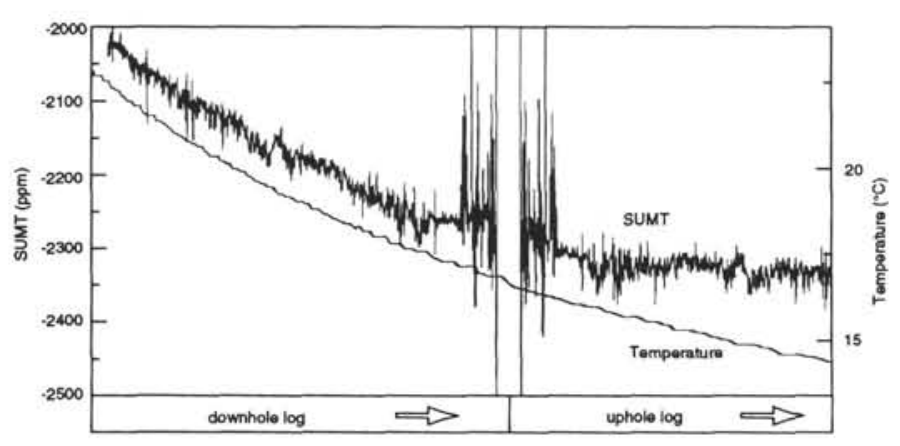

Figure 5. Hole 831B. Drift of the susceptibility sensor compared to the temperature drift. Raw susceptibility and temperature output from the SUMT are plotted with respect to elapsed time from downhole and successive uphole $\log$. Due to the low temperature of bottom sea water, the temperature of the tool decreased with time as the tool was lowered in the hole and during the following uphole run.

of the ship's heave effects and slight inaccuracies in depth, the average difference between two runs was determined for a window of $5 \mathrm{~m}$ with a single depth shift per window for a maximum correlation between the two runs. The correlation coefficient between the two runs is generally greater than 0.8 (Fig. 10). In good weather conditions, the heave compensator performed very well and the depth shift between the two logs was very small (Fig. 10). For most of the depth interval from 250 to $700 \mathrm{mbsf}$ there is an unexplained offset of about
Table 1. Magnetic characteristic properties of selected samples at Site 831 .

\begin{tabular}{llll}
\hline Sample & Depth (mbsf) & NRM intensity $(\mathrm{A} / \mathrm{m})$ & Susceptibility $\left(\times 10^{-5} \mathrm{SI}\right)$ \\
\hline 134-831B- & & & \\
16R-CC, 17-19 & 217.9 & 0.000035 & -0.6 \\
20R-CC, 17-19 & 256.2 & 0.000029 & -0.8 \\
27R-CC, 5-7 & 323.5 & 0.00140 & -0.5 \\
34R-CC, 5-7 & 391.0 & 0.00489 & 0.3 \\
36R-CC, 4-6 & 410.3 & 0.00411 & -0.5 \\
40R-CC, 17-19 & 449.1 & 0.000025 & -0.9 \\
48R-1, 11-13 & 525.5 & 0.000015 & -1.0 \\
51R-CC, 6-8 & 553.9 & 0.000037 & -0.8 \\
53R-CC, 13-15 & 573.4 & 0.000028 & -1.0 \\
57R-CC, 18-20 & 612.2 & 0.000037 & -1.0 \\
59R-CC, 8-10 & 631.4 & 0.000006 & -1.2 \\
63R-1, 98-100 & 670.2 & 0.000017 & -1.0 \\
64R-1, 78-80 & 679.3 & 0.000547 & -0.9 \\
66R-1, 78-80 & 698.6 & 0.000061 & -0.6 \\
68R-1, 24-26 & 717.3 & 0.000092 & -0.6 \\
\hline
\end{tabular}

$6 \mathrm{nT}$ between the two logs in contrast to the one expected from the base station record on Espiritu Santo Island. From 220 to $240 \mathrm{mbsf}$ there is a clear jump of about $2 \mathrm{nT}$ related to the motion of the pipe during the second run; the pipe was lifted up by a few tens of meters at the end of the second run. This procedure, commonly used to improve log recovery, obviously should be avoided during magnetic logging. From $250 \mathrm{mbsf}$ to $500 \mathrm{mbsf}$, the difference between the two runs is almost constant while the bottom part of the hole is slightly more perturbed. The average deviation around the mean difference for a window of $5 \mathrm{~m}$ is about 0.1 to $0.2 \mathrm{nT}$, which demonstrates the high resolution of the sensor.

Similarly to the susceptibility record, a high-frequency signal was removed by a low-pass filter (Fig. 11). The magnetic anomalies have amplitudes of less than \pm 2 nT. The most significant anomalies are observed from 325 to 400 mbsf. The few NRM measurements from the available samples suggest that despite a general nonmagnetic lithology, intensities up to several $10^{-3} \mathrm{~A} / \mathrm{m}$ can be found. The distribution of the magnetization is likely heterogeneous and may well account for the observed magnetic anomalies.

\section{DISCUSSION}

Magnetic susceptibility and total magnetic field measurements at Site 831 are compared in Figure 11. Uranium-thorium dating and isotopic strontium data indicate that the upper $330 \mathrm{~m}$ is younger than $1 \mathrm{Ma}$ (Quinn et al., this volume). No significant differences occur in the magnetic characteristics above and below $330 \mathrm{mbsf}$. We can, however, note that the most significant susceptibility and total field anomalies are observed between 325 to $400 \mathrm{mbsf}$, and this depth interval corresponds to the time when the guyot was exposed or shallowly submerged.

The latitude of the site is such that the contribution of the weak induced magnetization cannot be detected in total field measurements. There are, however, obvious correlations in the high-frequency signal. Zones of high-frequency variations (e.g., between 200 and $250 \mathrm{mbsf}$ and below $500 \mathrm{mbsf}$ ) correlate on both logs, whereas the susceptibility data and especially the total field data are featureless from 425 to $500 \mathrm{mbsf}$. Drilling at Site 831 was performed in seawater and no drilling mud cake lines the borehole wall. However, $150 \mathrm{~m}$ of andesitic volcanic rocks were drilled below the carbonate cap. The cuttings and associated volcanic muds circulated upward and 


\section{A}

Magnetic Susceptibility (ppm SI units)

Down

Up

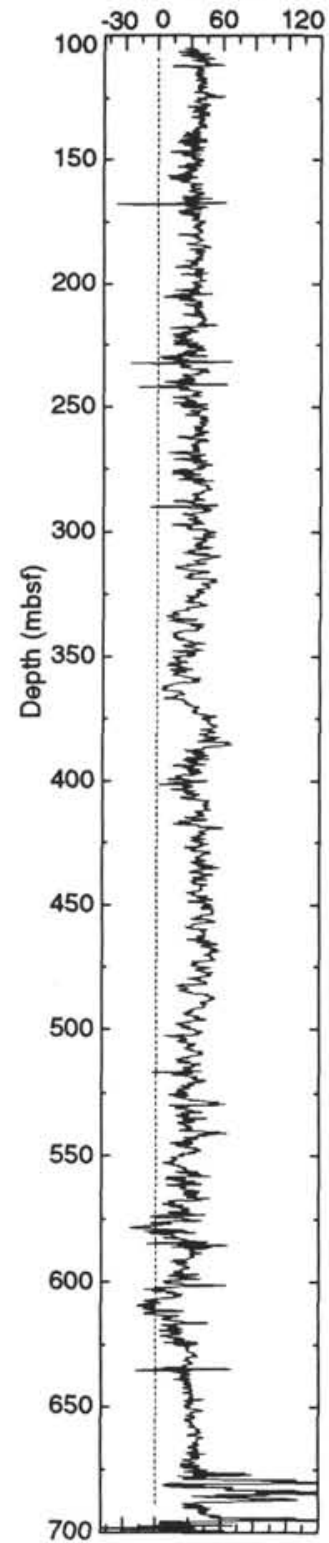

B

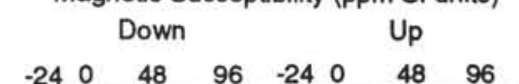

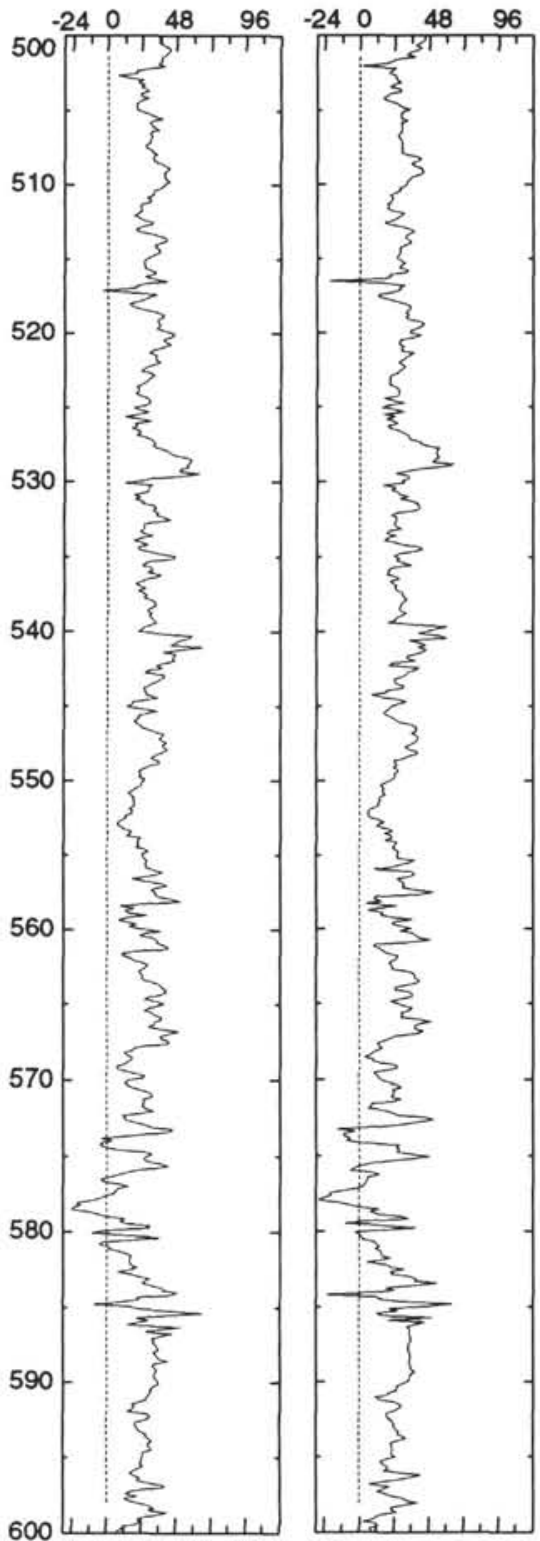

C Magnetic Susceptibility (ppm SI units) Down Up

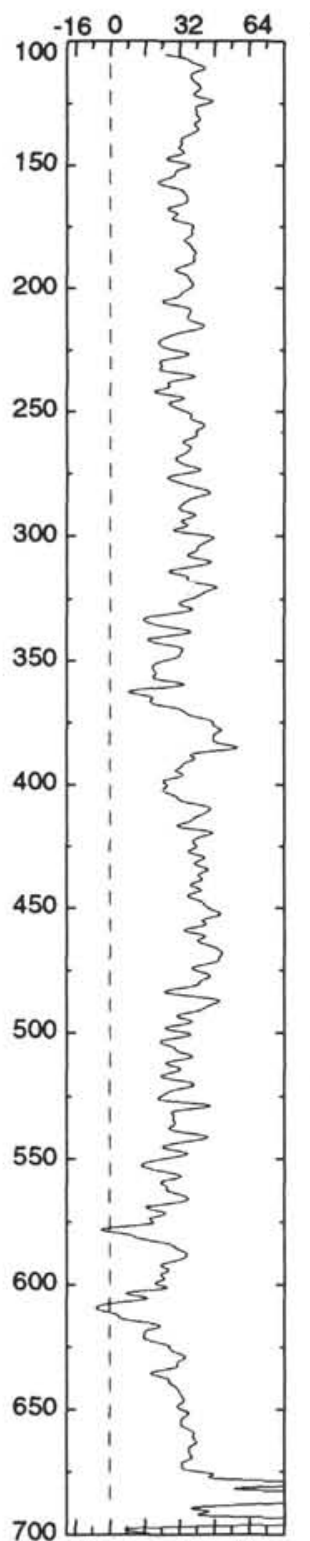

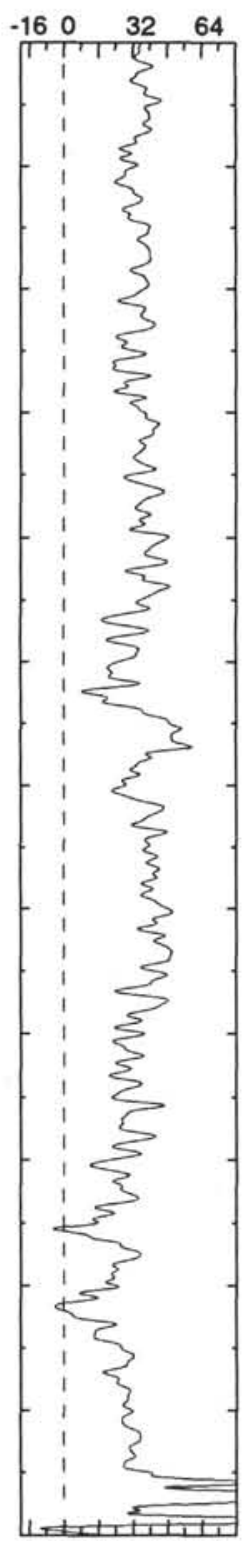

Figure 6. Hole 831B. Comparison of downhole and uphole SUMT records after drift corrections. A. Susceptibility record at Site 831 after temperature drift corrections (left) from 100 to $700 \mathrm{mbsf}$. B. Enlarged interval from 500 to $600 \mathrm{mbsf}$, which demonstrates the very good repeatability of the measurements on a meter scale. C. Comparison of the filtered (20pts \# 3-m) downhole and uphole logs. There is a depth shift of about $0.60 \mathrm{~m}$ between the downhole and uphole logs because of differences in cable stretch.

the possibility that a small amount of volcanic mud invaded the porous carbonate cannot be discarded. Contamination from the drilling pipe and volcanic rocks could explain the high-frequency signal.

Although the Bougainville Guyot has been near the New Hebrides Island Arc for the last few hundred thousand years, there is no evidence for thick layers (over $10 \mathrm{~cm}$ ) of volcanic ashes with corresponding susceptibility peaks in the upper $300 \mathrm{~m}$ of section according to the susceptibility record. However we cannot rule out the possibility that very thin ash layers are present. Thin ash layers $(<1 \mathrm{~cm})$ with magnetic susceptibility of about $10^{-2} \mathrm{SI}$ have been documented in the pelagic sediments on top of the guyot and the North d'Entrecasteaux Ridge. On average, the susceptibility log indicates a low paramagnetic background of about 3 to $4 \times 10^{-5}$ SI. A small amount of ash (a few parts per mil) mixed in coral reef deposits may explain the apparent discrepancy between discrete measurements and the SUMT log. Clays may also be thinly distributed within the porous carbonate. The gamma rays mostly reflect the uranium content, and corals are more efficient than mollusks in concentrating uranium from seawater. Thus, 


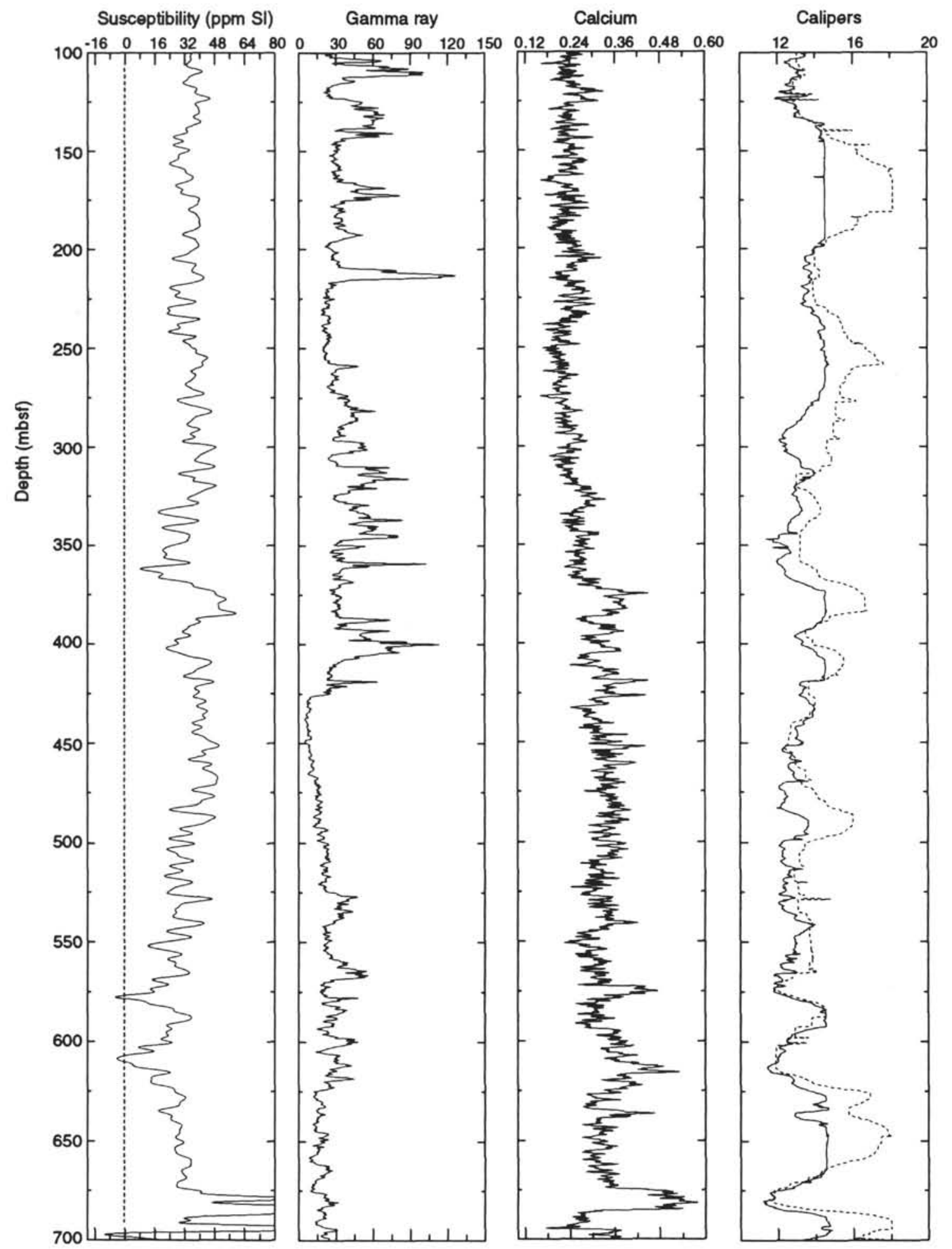

Figure 7. Hole 831B. Comparison of the filtered susceptibility (SI) data with the spectral gamma ray (API), the calcium index and the borehole calipers (in inches) from the formation microscanner.

it is difficult to assess clay amounts. From 425 to about 500 mbsf the quiet magnetic zone observed on the total field $\log$ (Fig. 11) correlates with a minimum in the gamma-ray log (Fig. 7), suggesting that the magnetic changes are also controlled by changes in the facies within the neritic carbonate rocks.

Measurements of discrete samples show stronger variations in intensity of magnetization than in susceptibility. Intensities up to about $5 \times 10^{-3} \mathrm{~A} / \mathrm{m}$ are observed. In contrast to the induced magnetization, the remanent magnetizations contribute to the total magnetic field signal. In the hypothesis of horizontal layers with an homogeneous distribution of remanent magnetizations collinear with the earth field, remanent magnetizations of about $10^{-2} \mathrm{~A} / \mathrm{m}$ will induce negative anomalies of about $-1.5 \mathrm{nT}$. The distribution of the magnetization is very likely heterogeneous within the neritic carbonate rocks, and the 
formation microscanner resistivity images do not show good evidence for layering. Thus, the interpretation of the total magnetic field signal is only tentative.

From 150 to $320 \mathrm{mbsf} \mathrm{U}$-Th radiometric data indicate that the neritic carbonate was deposited during the late Pleistocene within the Brunhes normal chron; the magnetic anomaly signal is low $(<1 \mathrm{nT}$ on the filtered $\log$ ). The most significant anomalies in susceptibility and total field data are found in the depth interval from 320 to about 420 mbsf(Fig. 11). Although the low induced magnetization is not expected to contribute to the total field signal, the correlation between the two signals may reflect changes in magnetic mineralogy, with a possible increase in the Koenigsberger ratio (i.e., a ratio of the remanent to the induced magnetization). Large changes in the Koenigsberger ratios are also observed using the discrete sample measurements. We may interpret the positive anomalies (320-350 mbsf and 370-420 mbsf) as evidence for a reversed period while the negative anomaly (350-370 mbsf) may correspond to a normal period, possibly the Jaramillo sub-chron. However the inclination of the remanent magnetization is not known accurately and may vary around $\pm 35^{\circ}$. The contribution of the remanent magnetization to the NRMT depends also on the inclination values of the remanent magnetization and the effect changes sign at the $\pm 35^{\circ}$ limit. Thus the interpretation of the total magnetic field anomaly at Site 831 is difficult without additional information. Below $420 \mathrm{mbsf}$ the low signal and the lithology of the whole-rock formation prevents any kind of interpretation.

\section{CONCLUSION}

The magnetic logging experiments performed at Sites 829 and 831 demonstrate that magnetic data can be used to help interpret and define lithostratigraphy. The magnetic logs at Site 831 indicate the carbonate cap of the Bougainville Guyot has developed in a very low magnetic environment, although the guyot has been close to aerial volcanic sources (ash). Neritic carbonates are obviously among the worst recorders of the geomagnetic field. So far very few magnetostratigraphic studies from coral core samples have been successful (Aïssaoui et al., 1990). The conglomerate nature of the guyot's carbonate cap and the likely heterogeneous distribution of the magnetization prevent a clear interpretation of the magnetic logs. Susceptibility contrasts observed in the susceptibility logs are slightly larger than those expected with the few measurements made on discrete samples. A small amount of clays or ash may have been distributed within the coral reef pores and washed away during drilling.

Results from Site 831 indicate that contamination from the drill pipe and the drill cuttings and mud is negligible and should not significantly affect borehole magnetic logs in more magnetized sediment such as deep-sea sediment. This observation supports the results of magnetic logs obtained in the Bassin de Paris (Augustin, 1990; Pozzi et al., 1988). The difference between the two total magnetic field runs at Site 831 demonstrates the high sensitivity of the NRMT sensor. However, magnetic anomalies of about $1 \mathrm{nT}$ are observed on a scale of a few tens to hundreds of meters, and we recommend that a double $\log$ be run in sediment and that the diurnal variations at a nearby reference station be recorded whenever possible.

Although magnetic downhole experiments are still at an early stage their development will improve the understanding of in-situ variations of magnetic properties with depth. The magnetostratigraphy based on measurements of whole cores or discrete samples is a very powerful method when all the conditions are met (i.e., magnetization of the order of $10^{-2} \mathrm{~A} / \mathrm{m}$, and very low secondary magnetization). Downhole magnetostratigraphy is expected to perform as well in the same magnetic conditions.

\section{ACKNOWLEDGMENTS}

We wish to thank Jean-Paul Foucher from IFFREMER, Claude Delas from TOTAL company, and the Schlumberger company, who made possible the magnetic logging test during Leg 134. ORSTOMNoumea is acknowledged for the installation of a reference magnetic station on Espiritu Santo Island. Laura Stokking and Janet Pariso made valuable suggestions to help improve this chapter.

\section{REFERENCES}

Aïssaoui, D.M., McNeill, D.F., and Kirschvinc, J.L., 1990. Magnetostratigraphy dating of shallow-water carbonates from Mururoa atoll, French Polynesia: implications for global eustasy. Earth Planet. Sci. Lett., 97:102-112.

Augustin, A., 1990. Diagraphies d'induction magnétique et de susceptibilité magnétique et de susceptibilité magnétique en forage [Thèse]. Univ. Joseph Fourier-Grenoble I, France.

Berggren, W.A., Kent, D.V., Flynn, J.J., and Van Couvering, J.A., 1985 Cenozoic geochronology. Geol. Soc. Am. Bull., 96:1407-1418.

Bosum, W., and Scott, J.H., 1988. Interpretation of magnetic logs in basalt, Hole 418A. In Salisbury, M.H., Scott, J.H., et al., Proc. ODP, Sci. Results, 102: College Station, TX (Ocean Drilling Program), 77-95.

Collot, J.-Y., Daniel, J., and Burne, R.V., 1985. Recent tectonics associated with the subduction/collision of the d'Entrecasteaux zone in the central New Hebrides. Tectonophysics, 112:325-356.

Collot, J.-Y., Greene, H.G., Stokking, L.B., et al., 1991. Proc. ODP, Init. Repts., 134: College Station, TX (Ocean Drilling Program).

Cox, A., 1983. A magnetic reversal time scale. In Harland W.B., Cox, A.V., Llewellyn, P.G., Pickton, C.A.G., Smith, A.G., and Walters, R. (Eds.), A Geologic Time Scale: Cambridge (Cambridge Univ. Press).

Edwards, R.L., Gallup, C.D., Taylor, F.W., Quinn, T.M., and ODP Leg 134 Scientific Party, 1991. ${ }^{230} \mathrm{Th} /{ }^{238} \mathrm{U}$ and ${ }^{234} \mathrm{U} /{ }^{238} \mathrm{U}$ in submarine corals: evidence for diagenetic leaching of ${ }^{234} \mathrm{U}$. Am. Geophys. Union fall meeting, Eos, 535.

Gallet, Y., and Courtillot, V., 1989. Modeling magnetostratigraphy in a borehole. Geophysics, 54:973-983.

Pariso, J.E., Scott, J.H., Kikawa, E., and Johnson, H.P., 1991. A magnetic logging study of Hole 735B gabbros at the Southwest Indian Ridge. In Von Herzen, R.P., Robinson, P.T., et al., Proc. ODP, Sci. Results, 118: College Station, TX (Ocean Drilling Program), 309-322.

Parker, R.L., and Daniell, G.J., 1979. Interpretation of borehole magnetometer data. J. Geophys. Res., 10:5467-5479.

Pocachard, J., Thomas, T., Barthès, V., Pagès, G., 1991. High resolution logging tool for borehole measurements of magnetization. IUGG, $X X$ Assembly, Vienna.

Ponomarev, V.N., and Nechoroshkov, V.L., 1983. First measurements of the magnetic field within the ocean crust: Deep Sea Drilling Project Legs 68 and 69. In Cann, J.R., Langseth, M.G., Honnorez, J., Von Herzen, R.P., White, S.M., et al., Init. Repts. DSDP, 69: Washington (U.S. Govt. Printing Office), 271-279.

, 1984. Downhole magnetic measurements in oceanic crustal Hole 395 A on the Mid-Atlantic Ridge. In Hyndman, R.D., Salisbury, M.H., et al., Init. Repts. DSDP, 78 (Pt. 2): Washington (U.S. Govt. Printing Office), 731-739.

Pozzi, J.-P., Martin, J.P., Pocachard, J., Feinberg, H., and Galdeano, A., 1988. In situ magnetostratigraphy: interpretation of magnetic logging in sediments. Earth Planet. Sci. Lett., 88:357-373.

Quinn, T.M., Taylor, F.W., Halliday, A.N., Collot, J.-Y., Greene, H.G., and ODP Leg 134 Scientific Party, 1991. Sr Isotopic dating of carbonate at Bougainville Guyot (Site 831) New Hebrides arc. Am. Geophys. Union fall meeting, Eos, 535.

Tabbagh, A., Pozzi, J.-P., Alvarez, F., Pocachard, J., Martin, J.-P., Pages, G. Gable, R., Lebert, F., and Hutin, R., 1990. Magnetic field and susceptibility logging in GPF3 borehole at Couy (France) between 0 and $3500 \mathrm{~m}$. Geophys. J. Int., 101:81-88.

Taylor, F.W., Quinn, T.M., Gallup, C.D., Edwards, R.L., Collot, J.-Y., Greene, H.G., and ODP Leg 134 Scientific Party, 1991. Plate tectonic implications from coral stratigraphy of the Bougainville Guyot, New Hebrides arc. Am. Geophys. Union fall meeting, Eos, 535.

Date of initial receipt: 29 April 1992

Date of acceptance: 4 January 1993 Ms 134SR-036

-Abbreviations for names of organizations and publications in ODP reference lists follow the style given in Chemical Abstracts Service Source Index (published by American Chemical Society). 
P. ROPERCH ET AL.

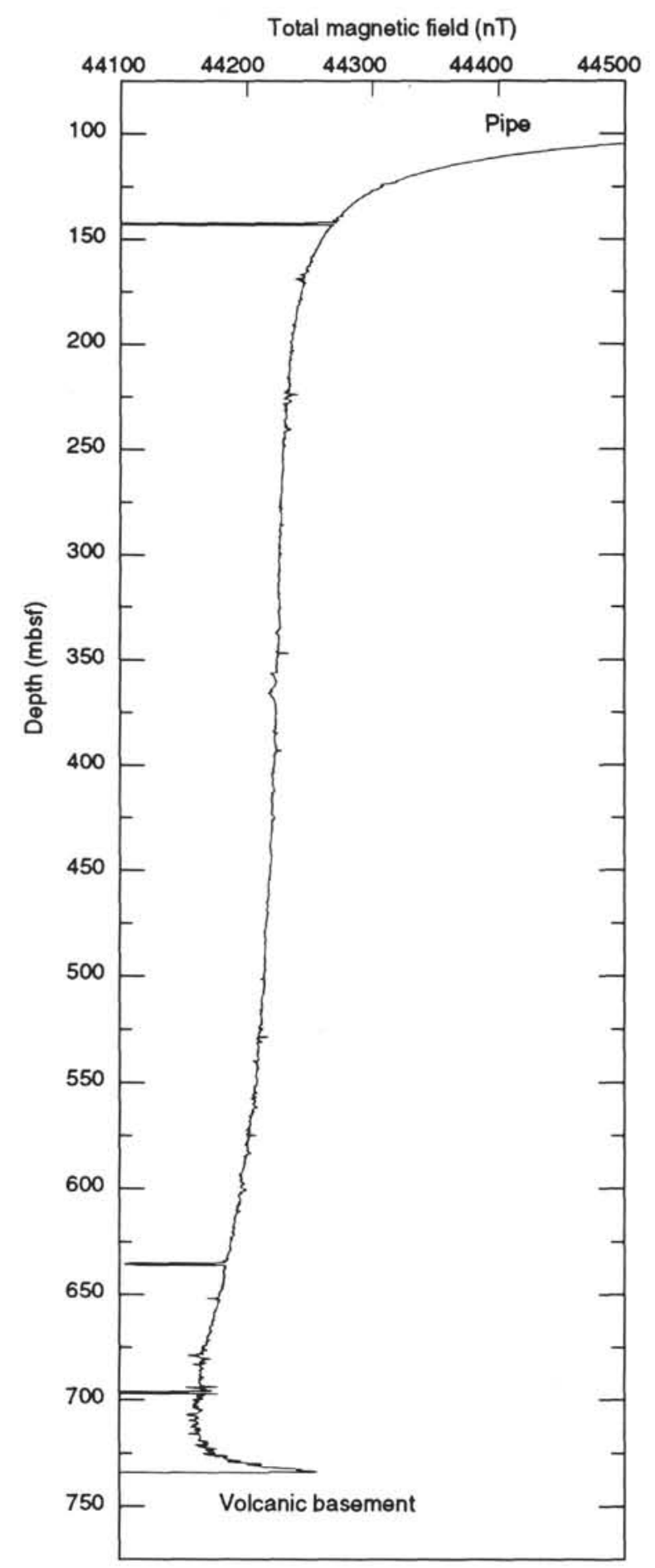

Figure 8. Raw NRMT total magnetic field record at Hole 831B. 
Total magnetic field (nT)

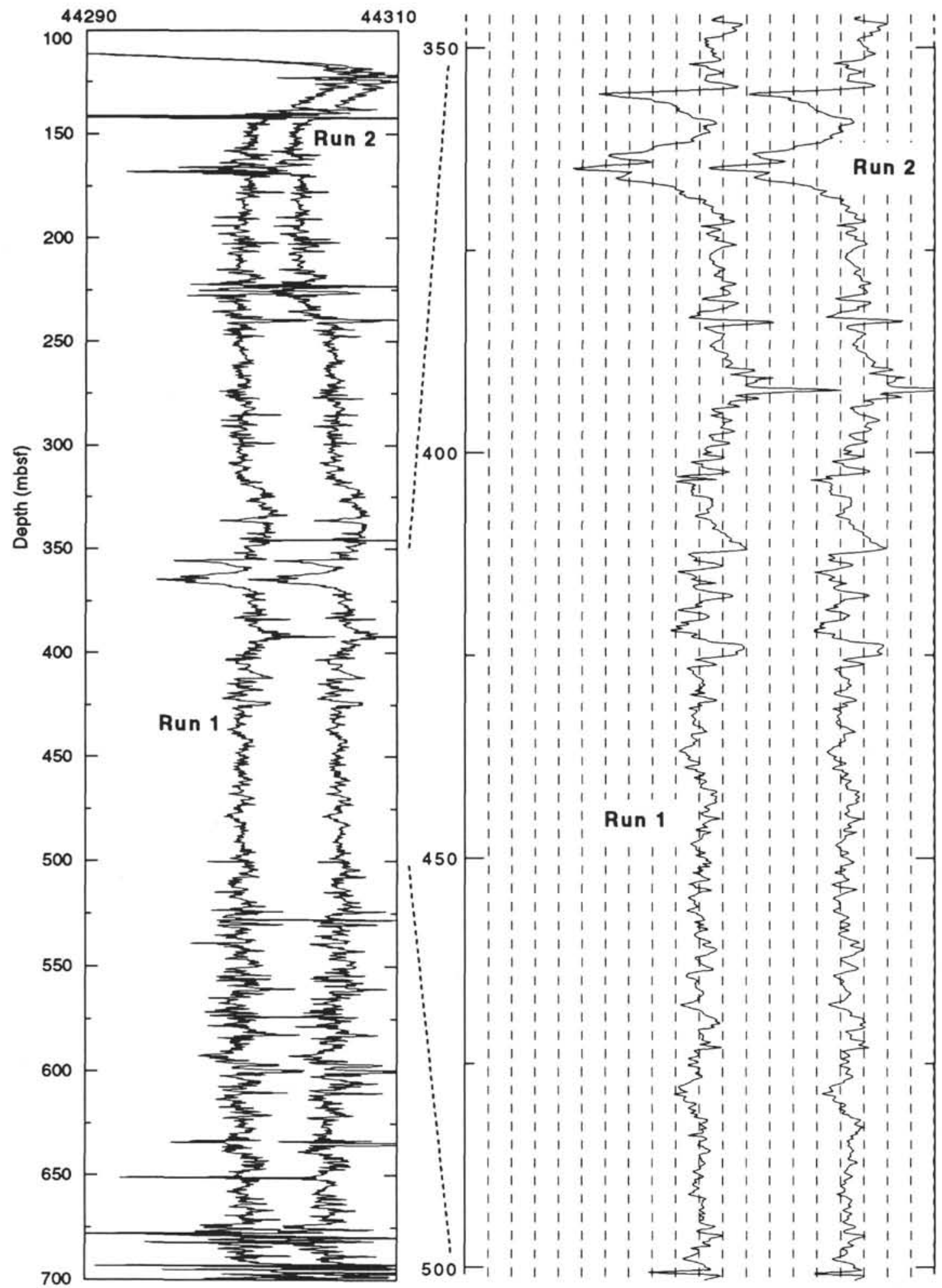

Figure 9. Hole 831B. Comparison of two runs showing the excellent repeatability of total field measurements. The enlarged section from 350 to $500 \mathrm{mbsf}$ shows that magnetic anomalies of less than $\mathrm{InT}$ are reproducible. The spacing between dashed lines is $1 \mathrm{nT}$. 
Correlation coefficient

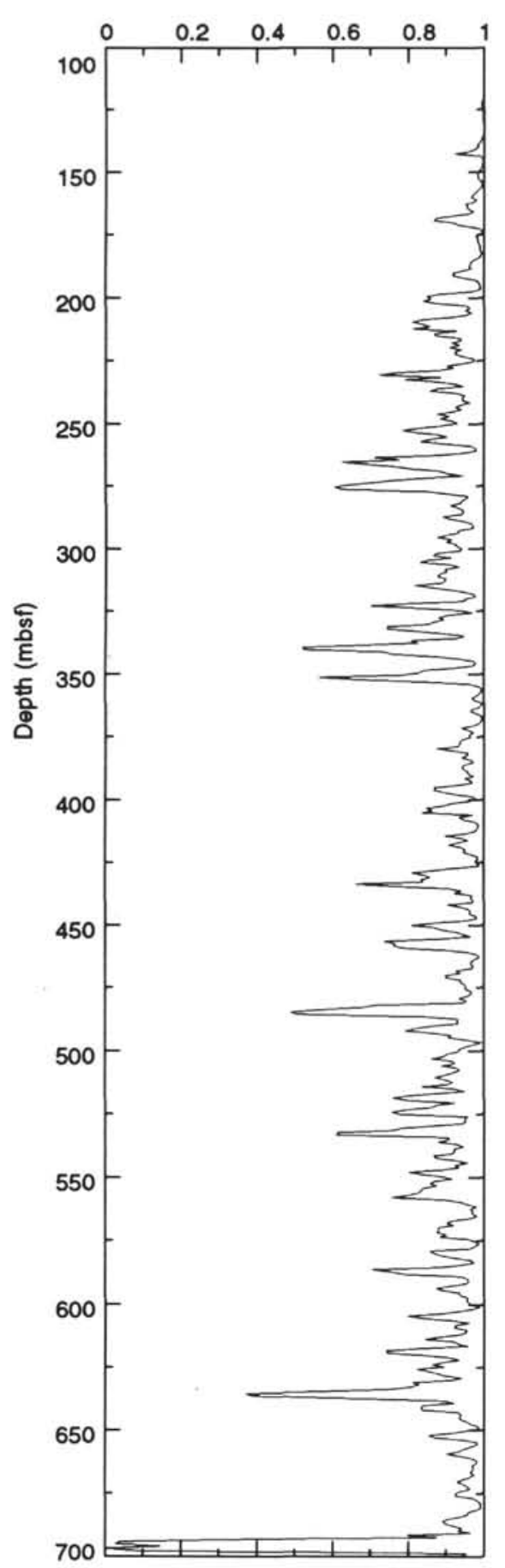

Depth shift (m)

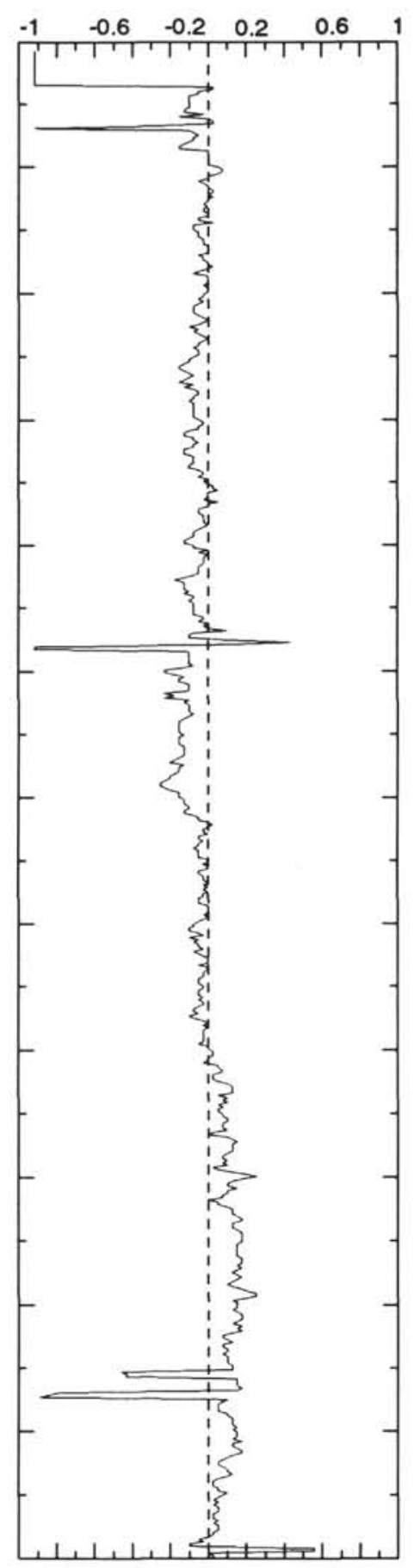

Difference

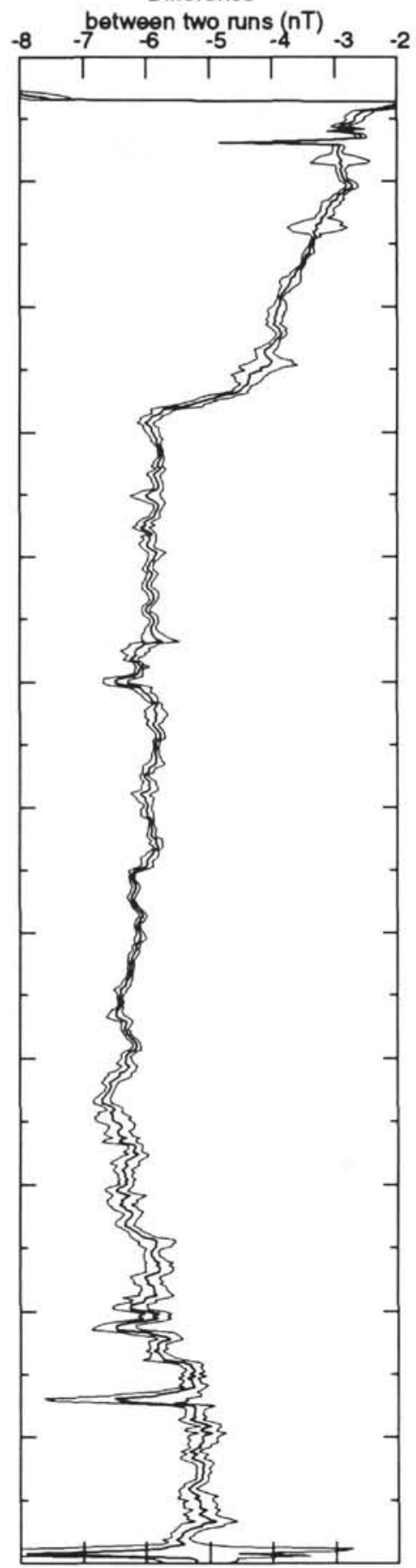

Figure 10. Hole 831B. Spearman rank-order correlation coefficients, optimal depth shift, and difference between two runs. A 5-m window was used to calculate the correlation coefficient. A sampling by linear interpolation was used to refine the depth shift. The mean difference for each 5-m window and the average deviation were calculated using the median calculation. The 5-m window was moved by $1-\mathrm{m}$ steps. 
Magnetic susceptibility (ppm SI)
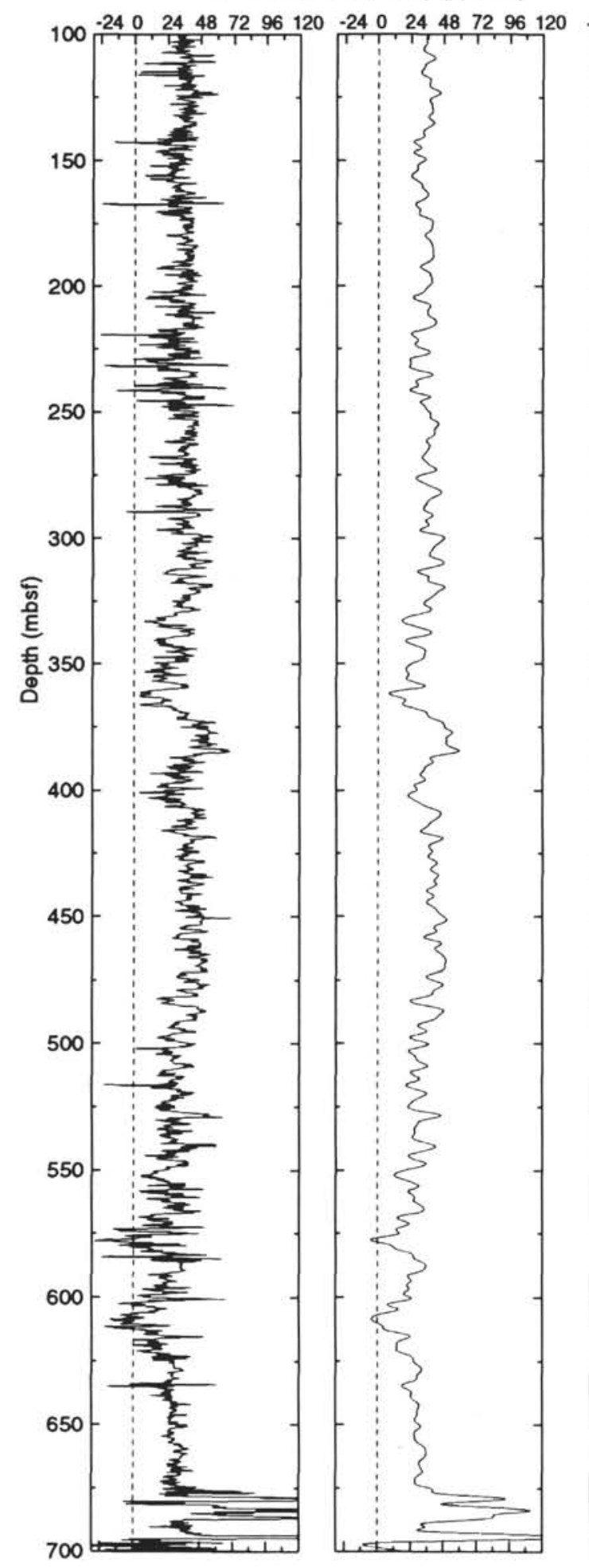

Magnetic field anomaly $(\mathrm{nT})$

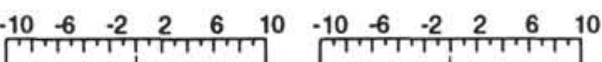

Figure 11. Comparison of the SUMT susceptibility data with NRMT total magnetic field measurements at Hole 831B before and after filtering. 